\section{Interactive Effects of Light and Chilling on Peach Flower and Leaf Budbreak}

\author{
William R. Okie ${ }^{1}$ and Bryan Blackburn \\ USDA-ARS, Southeastern Fruit and Tree Nut Research Laboratory, 21 \\ Dunbar Road, Byron, GA 31008
}

Additional index words. Prunus persica, dormancy, chilling

\begin{abstract}
Timing of budbreak in response to winter chilling is a critical factor in the suitability of peach [Prunus persica (L.) Batsch] cultivars to moderate climates such as that in the southeastern United States. Much of the research on chilling and dormancy has used excised cuttings or potted trees exposed to various treatments and forced under controlled conditions. Light is not generally considered an important factor in such experiments, and the effect of light during forcing has been little studied. The objective of this research was to compare light versus dark conditions during forcing as well as the effects of different colors of light during forcing. Our results showed that after chilling had been minimally satisfied, peach floral and vegetative budbreak occurred faster when forced in the presence of light than when forced in darkness. Light increased budbreak rate as well as the total percentage of budbreak. Red, yellow, and fluorescent light were more promotive in increasing budbreak than blue, green, infrared, or incandescent light, suggesting a role for phytochrome. Promotive effects of light were less when buds had received enough natural chill and heat to break within a week of forcing at $18{ }^{\circ} \mathrm{C}$. In conclusion, light during forcing can have a significant effect of budbreak and needs to be considered when doing research on chilling and dormancy.
\end{abstract}

In areas with cold winters, chilling is more than adequate for normal budbreak and growth of fruit crops, and time of bloom is primarily dependent on onset of warmer temperatures. In the southeastern United States and similar climates, winter chilling can be quite variable, which can impact fruit production. For successful peach production, cultivars must be chosen to match the typical local chilling regime such that adequate chilling is received for normal development but bloom is late enough to avoid frosts. Peach trees forced into bloom after insufficient chilling break leaf and flower buds slowly and erratically, if at all (Chandler et al., 1937; Weinberger, 1950b).

Measures of chilling associated with the major horticultural dormancy models include the Weinberger "chill hours" (Weinberger, 1950a), the Utah weighted "chill units" (Anderson et al., 1986; Richardson et al., 1974), and the Dynamic Model "chilling portions" (Erez et al., 1990; Fishman et al., 1987). Other models have been proposed for use with forest trees (Hanninen and Kramer, 2007; Harrington et al., 2010; Linkosalo et al., 2006).

Weinberger (1950a) showed that in Georgia, a higher number of winter hours at temperatures $7.2^{\circ} \mathrm{C}$ or less (originally $45^{\circ} \mathrm{F}$ ) was found to correlate with normal budbreak and fruit set. In years with lower numbers of such hours by 15 Feb., some cultivars bloomed er-

Received for publication 18 Oct. 2010. Accepted for publication 11 Apr. 2011.

${ }^{1}$ To whom reprint requests should be addressed; e-mailwilliam.okie@ars.usda.gov. ratically and fruit set was poor (Weinberger, 1950a). The 15 Feb. correlation likely reflects the fact that temperatures usually begin warming in mid- to late February in central Georgia, so subsequent chilling is less effective. Originally this minimum "chilling requirement" was determined for a cultivar by forcing twigs at intervals during the winter and noting if 50\% budbreak occurred in 3 weeks (Weinberger, 1950a). In recent years, breeders in moderate climates have estimated chill requirement by comparing bloom time with that of previously rated cultivars under the assumption that cultivars with the same requirement will usually bloom at about the same time. Although the chill hour scale is crude, growers have an idea of the relative bloom time of a given chilling rating and the corresponding probability of adaptation to their climate. The chill hour model is easy to understand and calculate and is still used to describe cultivar chilling requirement (Okie, 1998). Although "chill hours" are defined as distinct from "chill units," these terms are often used interchangeably, particularly when used to rate cultivar chilling requirement.

Utah weighted chill units (cu) were initially defined using a simple step function (Richardson et al., 1974; Seeley, 1996), wherein $1 \mathrm{~h}$ in the optimum chilling temperature range was defined as $1 \mathrm{cu}$ with each hour at lower or higher temperature counting less than $1 \mathrm{cu}$. The model was subsequently refined into a series of three curves representing shelter, bud, and effective temperatures (Anderson et al., 1986; Richardson et al., 1986; Seeley, 1996). Many later papers by others refer only to the initial step func- tion model, perhaps because revisions of the model appeared only in proceedings of meetings. More recent studies with other crops have suggested that slightly higher and lower temperatures may also have some chilling effect (Harrington et al., 2010; Mahmood et al., 2000). The Utah chill models allow warm temperature to cause unlimited negation of previous chilling, which is a problem in climates with extended warm spells in winter (Allan et al., 1995; Erez et al., 1979; Linsley-Noakes et al., 1995). The Dynamic Model avoids the negation issue by making accumulated chilling irreversible if subsequent temperatures are cool. The Utah models also proposed to start accumulating chilling when negated chilling reaches the lowest (most negative) value in the fall, but this idea makes more sense in a colder climate where winter has a more clearcut beginning (Seeley, 1996). The 1986 version of the Utah model added the ASYMCUR GDH heat accumulation model (Anderson et al., 1986; Richardson et al., 1986), allowing actual prediction of bloom time in contrast to the previous versions, which addressed only the satisfaction of the chilling requirement. The limitations of the sequential nature of the Utah models (chilling, then heat accumulation) relative to use in moderate climates has been recognized (Seeley, 1996).

The mentioned models treat dormancy breaking as two sequential processes. Others have suggested the processes to be parallel with the chilling and heat accumulation phases overlapping during the transition from one to another (Harrington et al., 2010; Okie and Blackburn, 2011). This overlap would be more important in moderate climates where chilling accumulation is of concern.

Short days are known to speed dormancy induction in some tree species (Heide and Prestrud, 2005; Tanino et al., 2010). In beech (Fagus sylvatica L.), bud dormancy was thought to be induced by short days and released by long days (Waring, 1953). More recent work (Falusi and Calamassi, 1990) shows that this photoperiodic effect is somewhat of a special case and that temperature (chilling) has a major effect in dormancy release even in beech. In Malus and Prunus, photoperiod seems to have little role in dormancy induction and release, at least relative to temperature (Heide, 2008; Heide and Prestrud, 2005).

Research on fruit tree dormancy often involves use of excised twigs or small trees subjected to various temperature treatments to observe the effects on budbreak. The role of light during chilling and forcing has not been considered very important and thus is not well studied. Many studies that used artificial chilling treatments did so in chambers without supplemental light (Erez et al., 1966; Lavee and Erez, 1969), perhaps because fluorescent lights work poorly in cold conditions. Forcing was often done in rooms or chambers with artificial light (usually fluorescent but sometimes unspecified) or in greenhouses using natural daylight. Erez et al. (1966) suggested that peach leaf budbreak is 
phytochrome-dependent and thus needs a light stimulus in contrast to flower budbreak, which was inhibited by light during budbreak in their study. Phytochrome is a chromoprotein that changes state depending on light spectrum and is involved in many aspects of plant growth and development. The inactive form $P_{r}$ is formed in darkness or in light with a low red:far-red ratio. Red light such as that in sunlight transforms $\mathrm{P}_{\mathrm{r}}$ into the active form, $\mathrm{P}_{\mathrm{fr}}$ (Smith, 2000). Bud scales are known to filter the light that reaches the apical dome (Pukacki et al., 1980; Pukacki and Giertych, 1982). Peach has been little studied in this regard, but Solymosi and Boddi (2006) showed transmission through peach bud scales (presumably vegetative buds) to be $5 \%, 19 \%, 10 \%$, and $97 \%$ at 440 , 650,680 , and $750 \mathrm{~nm}$, respectively. This selective transmission would tend to favor lower red:far-red ratios, because transmission of far-red (greater than $700 \mathrm{~nm}$ ) wavelengths is much more efficient than that of red wavelengths (600 to $700 \mathrm{~nm}$ ).

Lavee and Erez (1969) compared the effects of color-filtered light during forcing on floral and leaf budbreak of "dormant" (but harvested in early spring) peach twigs given an additional $21 \mathrm{~d}$ of chilling in the dark. White (cool-white fluorescent) and red light slightly enhanced leaf budbreak, whereas green light and darkness (slightly) enhanced floral budbreak. They also found leaf budbreak was greater and flower budbreak was less when forced in light compared with dark for twigs given $89 \mathrm{~d}$ artificial chilling in the dark. However, reduced natural light during middormancy enhanced subsequent leaf budbreak (Erez et al., 1968). Freeman and Martin (1981) reported that low-light [60 to 120 $\mu \mathrm{mol} \cdot \mathrm{m}^{-2} \cdot \mathrm{s}^{-1}$ photosynthetic photon flux density $(P P F D)$ ] during chilling enhanced peach floral budbreak by $5 \%$ to $10 \%$ compared with light $10 \times$ stronger, after plants were moved to the greenhouse to allow budbreak.

In the course of conducting research on chilling, we noticed that, in contrast to a previous report (Lavee and Erez, 1969), fluorescent growth chamber lights during forcing enhanced floral budbreak of excised twigs relative to those held in the dark. One purpose of this research was to study the interactive effects of light and chilling on peach budbreak under our conditions. A second purpose was to compare the effects of different colors of light on budbreak through the use of light-emitting diode (LED) bulbs with narrow spectrums, which were unavailable when the earlier work was done. Although there are limitations on manipulation of light in the orchard setting, any effects from the light regime could influence experimental results and the models developed from such studies.

\section{Materials and Methods}

Trees of 'Flordaprince' (with a traditional chilling requirement of 150 chill h), 'Flordadawn' (300 chill h), 'Juneprince' (625 chill h), and 'Sunland' (750 chill h) (Okie, 1998) were planted in 2002 at the ARS-USDA
Southeastern Fruit and Tree Nut Research Laboratory in Byron, GA (lat. $32.7^{\circ} \mathrm{N}$, long. $83.7^{\circ} \mathrm{W}$, elev. $160 \mathrm{msl}$ ) and managed following commercial recommendations. Eight adjacent trees per cultivar were randomly used as source trees for twigs. Orchard temperatures during the winter were recorded every 15 min in a weather shelter located $\approx 2 \mathrm{~km}$ from the experimental orchard. Chilling accumulation was estimated from these temperatures starting 1 Oct. by calculating Byron chill units (bcu), which used an approximation of the Utah model "effective chilling temperature" curve (Anderson et al., 1986), but in which negation from high temperatures was limited to the amount of the current and previous day's chilling.

All tests used excised twigs of the previous season's upright growth, basally trimmed to $\approx 30 \mathrm{~cm}$ length, with a basal diameter of $\approx 4$ to $5 \mathrm{~mm}$. Twigs were placed singly in $25 \times$ 95-mm polystyrene Drosophila vials (VWR International, West Chester, PA). Each treatment consisted of a rack of 12 twigs per cultivar. Vials were filled with Floralife Crystal Clear (Floralife Inc., Walterboro, $\mathrm{SC})$ at double strength $(2 \times=32 \mathrm{~mL} / \mathrm{L}$ water; $\mathrm{pH}=2.78$; soluble solids $=1.4 \%$ ). Crystal Clear contains no hormones and did not affect rate of budbreak in comparison with water but did reduce bacterial growth in the water and extend twig viability (data not shown).

Light versus dark. For light/dark treatments, twigs were usually cut weekly starting when field chilling was roughly $100 \mathrm{bcu}$ below its traditional chill requirement in chill $\mathrm{h}$ and ending when floral budbreak was visible on the trees. Prior experience showed that, although these were different systems of calculating chilling, there was enough correspondence that at least a few of the buds would at this time be responsive to forcing. In 2006-2007, starting cut dates (and bcu accumulations) were: 'Flordaprince', 9 Nov. (122 bcu); 'Flordadawn', 23 Nov. (272 bcu); and 'Juneprince' and 'Sunland', 25 Jan. (798 bcu). In 2007-2008, starting cut dates were 'Flordaprince', 16 Nov. (90 bcu); 'Flordadawn', 30 Nov. (187 bcu); 'Juneprince', 28 Dec. (442 bcu); and 'Sunland', 18 Jan. (614 bcu). Cut twigs went directly from the field into the forcing chambers. In 2008-2009, 'Sunland' cuttings were taken on 2 Jan. (543 bcu) and given 4,8 , or $12 \mathrm{~d}$ chilling in the dark at $4{ }^{\circ} \mathrm{C}$ and then moved to the forcing chamber.

For forcing, twigs were held in unreplicated growth chambers (I-66VL incubator; Percival Scientific, Perry, IA) maintained at $18.3 \pm 1{ }^{\circ} \mathrm{C}$, except for 2008-2009 when a $24{ }^{\circ} \mathrm{C}$ treatment was also used. The $18.3{ }^{\circ} \mathrm{C}$ temperature was chosen to be high enough to avoid further chilling accumulation and low enough to allow maximum budbreak of marginally chilled treatments. Temperatures within the chambers were monitored using Hobo H08-030-08 data loggers (Onset, Bourne, MA). Light treatments (diurnal cycles of either 12 or $24 \mathrm{~h}$ of light/day) were provided by the internal fluorescent lighting
(F32T8 TL741 Alto; color temperature $4100 \mathrm{~K}$; Phillips Lighting, Somerset, NJ). Spectral irradiance and $P P F D$ of light sources were quantified with an LI-1800 portable spectroradiometer (LI-COR, Lincoln, NE) with the sensor at $\approx 25 \mathrm{~cm}$ from the bulb. Twigs were briefly removed from the chamber daily to evaluate budbreak. When flower buds showed green scales, they were considered broken and were counted. These buds were then removed because the twigs were unable to sustain flower development for an extended period without collapse and because it greatly reduced the time needed to rate the twigs each day. Emergence dates of the terminal, first (in time) lateral, and third (in time) lateral vegetative buds were noted when green leaf tissue was visible $(\approx 2 \mathrm{~mm}$ leaf extension). Vegetative buds were left intact. After 5 to 6 weeks, remaining apparent flower buds (based on location and shape) were counted to calculate percent budbreak.

For the 2008-2009 test only, cuttings were placed in $28 \times 46 \times 34-\mathrm{cm}$ black (but painted white inside) plastic file boxes with either a black or translucent plastic bag covering the front in a chamber with a 12-h diurnal cycle. Light levels were reduced $\approx 10 \%$ by the translucent cover and $98 \%$ by the black cover. Temperature was $\approx 0.5^{\circ} \mathrm{C}$ cooler in the dark box. To minimize light effects during rating, boxes were opened only twice weekly for evaluating bud development.

Color of light. For color tests in 20062007, 'Juneprince' twigs were cut 25 Jan. (798 bcu) and 'Sunland' 1 Feb. (897 bcu) and 15 Feb. (1081 bcu). Twigs were placed directly in forcing chambers set at $21 \pm 2{ }^{\circ} \mathrm{C}$ with $24 \mathrm{~h}$ light of colors red, blue, and yellow plus dark (Fig. 1). Specific colored light treatments (Fig. 1) used R30 style floodlight bulbs (12 $\mathrm{V}$ or $120 \mathrm{~V}$, each containing 120 LEDs; LEDtronics, Torrance, CA). Specific bulb types and $P P F D$ for each color were: blue (Type 0PB, $18.9 \mu \mathrm{mol} \cdot \mathrm{m}^{-2} \cdot \mathrm{s}^{-1}$ ), green $(0 \mathrm{AG}$, 268.3), yellow (0PY, 21.2), red (0ER, 27.2), and infrared $(851,0)$.

In 2007-2008, twigs of 'Sunland' (trees planted in 1993) were cut $31 \mathrm{Dec}$. (437 bcu) and then given an additional chilling $\left(4^{\circ} \mathrm{C}\right.$ in the dark) for treatment levels of $\approx 800,900$, and 1000 total bcu. Racks were then placed inside the mentioned file boxes with lids inside a dark chamber at $18.3^{\circ} \mathrm{C}$. A conical utility light reflector with bulb was mounted on top of the box so the LED bulb shined through a $12-\mathrm{cm}$ hole in the box. Boxes with LED lights remained at chamber temperature. An incandescent source (Phillips Lighting, Somerset, NJ; 7.5 W nightlight, 4.4 $\left.\mu \mathrm{mol} \cdot \mathrm{m}^{-2} \cdot \mathrm{s}^{-1} P P F D\right)$ provided a predominantly far-red treatment. This box was left uncovered (but in a dark chamber) because of the slight heat generated by the nightlight. Lights were set to a 12-h diurnal cycle. A dark control was placed in a box without a bulb. A comparison rack was set up in a similar chamber set to a 12-h diurnal cycle using the growth chamber's internal fluorescent lights $\left(24.4 \mu \mathrm{mol} \cdot \mathrm{m}^{-2} \cdot \mathrm{s}^{-1} P P F D\right)$. Broad band red:far-red ratios for each light source 
were calculated using total irradiance in the ranges 600 to $700 \mathrm{~nm}$ for red and 700 to 800 $\mathrm{nm}$ for far-red.

\section{Results and Discussion}

Light versus dark. Floral budbreak followed a similar pattern over years and cultivars (Fig. 2; data for 'Flordaprince' and 'Flordadawn' not shown) occurring more rapidly with each successive cutting date. 'Sunland' was typical; as natural chilling increased over each successive week, floral budbreak began sooner, proceeded at a faster rate, and reached a higher final percentage (Fig. 3). The increased budbreak percentage each week suggests there is a wide range of chilling requirement among the buds of a single cultivar. Others (Freeman and Martin, 1981; Gariglio et al., 2006; Okie and Blackburn, 2011) noted a similar increase in percent budbreak as well as rate of budbreak from increased chilling. At the later dates for a given cultivar, the natural heat accumulated in the orchard would also have contributed to more rapid budbreak. In 2008-2009, when supplemental chilling was provided without added heat, higher chilling again increased floral budbreak rate (Fig. 4).

Exposure to fluorescent lights during forcing increased the rate of floral budbreak at the earlier sampling dates for each of the four cultivars (Fig. 2). In 2006-2007, selected sampling dates included both 12-h (data not shown) and 24-h diurnal cycles. Continuous (24 h) light was only slightly more promotive than a $12-\mathrm{h}$ cycle. For example, time to $30 \%$ budbreak for 'Sunland' after 897 bcu was 15,19 , and $38 \mathrm{~d}$ for $24-\mathrm{h}$ diurnal, 12-h diurnal, and dark treatments, respectively (Fig. 2A). Therefore, in 20072008, a 12-h diurnal cycle was used, which more closely resembled the natural daylength. Results in 2007-2008 using $12 \mathrm{~h}$ light compared with dark (Fig. 2B) were similar to those of 2006-2007 (Fig. 2A). The effects of light on buds of 'Sunland' (Fig. 3) were typical of the other cultivars. Usually budbreak was minimal at the first cutting date, especially for the dark treatment. In fact, budbreak did not reach $30 \%$ for the following treatments (Fig. 2): 'Juneprince' (20072008: 442 bcu both, 469 bcu dark, 500 bcu dark) and 'Sunland' (2006-2007: 798 bcu dark; 2007-2008: 614 bcu dark). Light not only increased the rate of floral budbreak, but also enabled some buds to break that would not have otherwise, thus increasing total budbreak. The light enhancement effect declined on twigs cut several weeks later when chilling was substantially above the chilling requirement such as 'Sunland' cut after 1000 bcu (Fig. 2). At this point, presumably all flower buds had received adequate natural chilling as well as substantial heat under natural daylight conditions, and not surprisingly, budbreak occurred rapidly with or without light during experimental forcing.

In 2008-2009 (Fig. 4), cuttings were only rated twice weekly, which minimized exposure to light for the dark treatments. Although

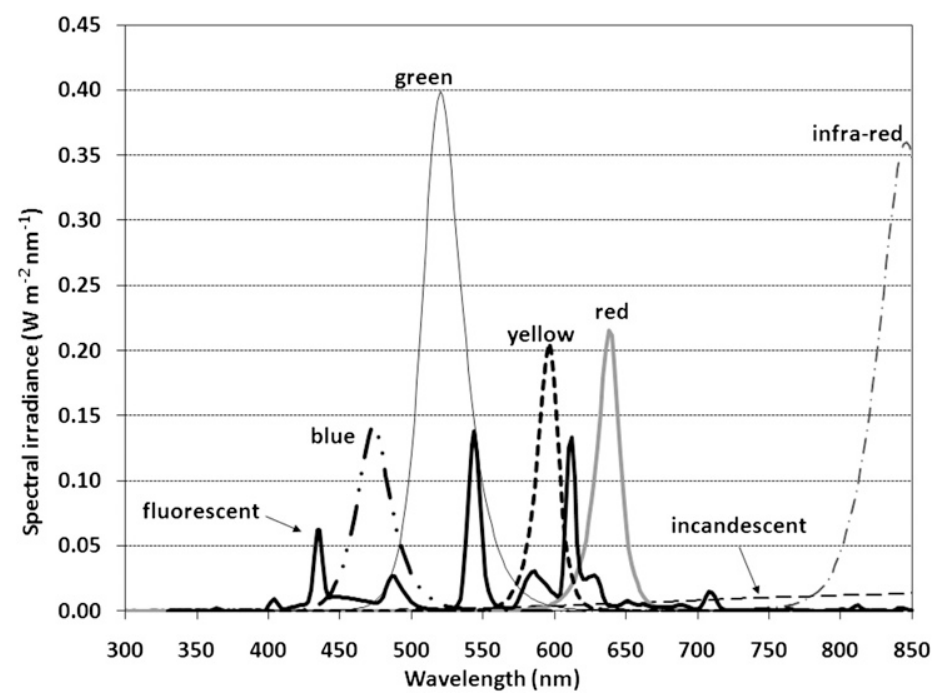

Fig. 1. Spectral irradiance of fluorescent, light-emitting diode (LED), or incandescent light sources used to illuminate peach twigs during forcing and budbreak.
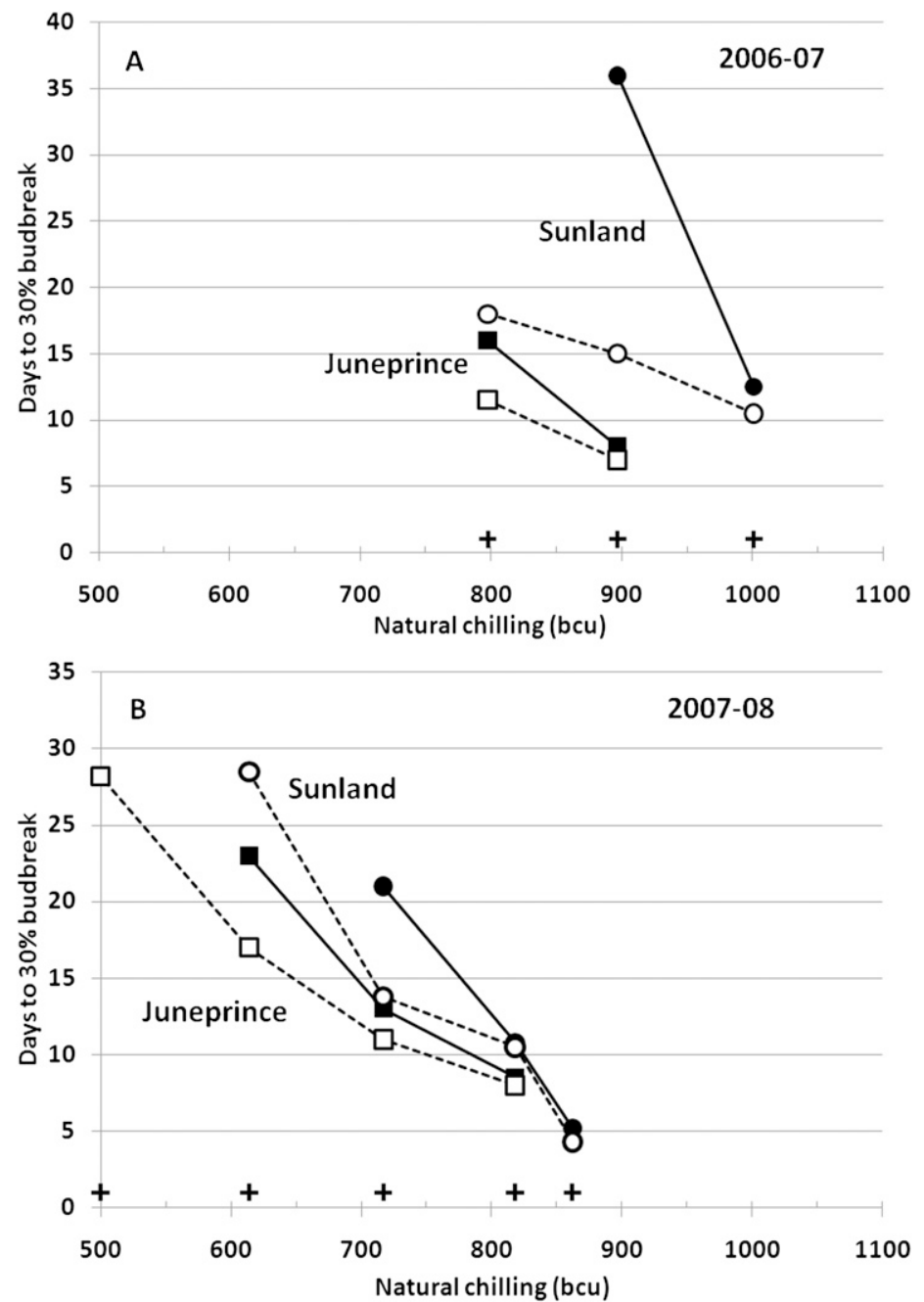

Fig. 2. Effect of light during forcing $\left(18.3^{\circ} \mathrm{C}\right)$ on floral budbreak of peach twigs cut weekly. Light treatments (open symbols) were diurnal light cycle of $24 \mathrm{~h}$ in 2006-2007 (A) and $12 \mathrm{~h} \mathrm{in} \mathrm{2007-2008}$ (B). Lines connect sequential sampling dates, which are plotted by Byron chill units (bcu) on that date. Plus signs along the $\mathrm{x}$-axis indicate sampling dates. Where dark treatment (solid symbol) is missing for that sampling date, budbreak did not reach $30 \%$. 


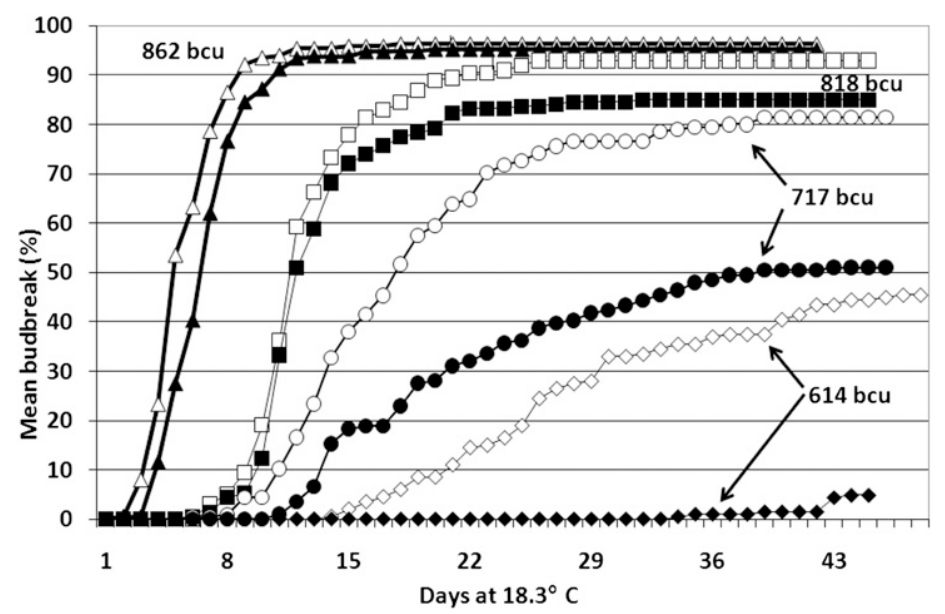

Fig. 3. Effect of light on budbreak of 'Sunland' peach flower buds. Twigs exposed during forcing at $18.3{ }^{\circ} \mathrm{C}$ to darkness (dark symbols) or diurnal cycle with $12 \mathrm{~h}$ light (open symbols). Twigs cut from orchard weekly over 4 weeks with 2007-2008 natural chill indicated (bcu = Byron chill units).
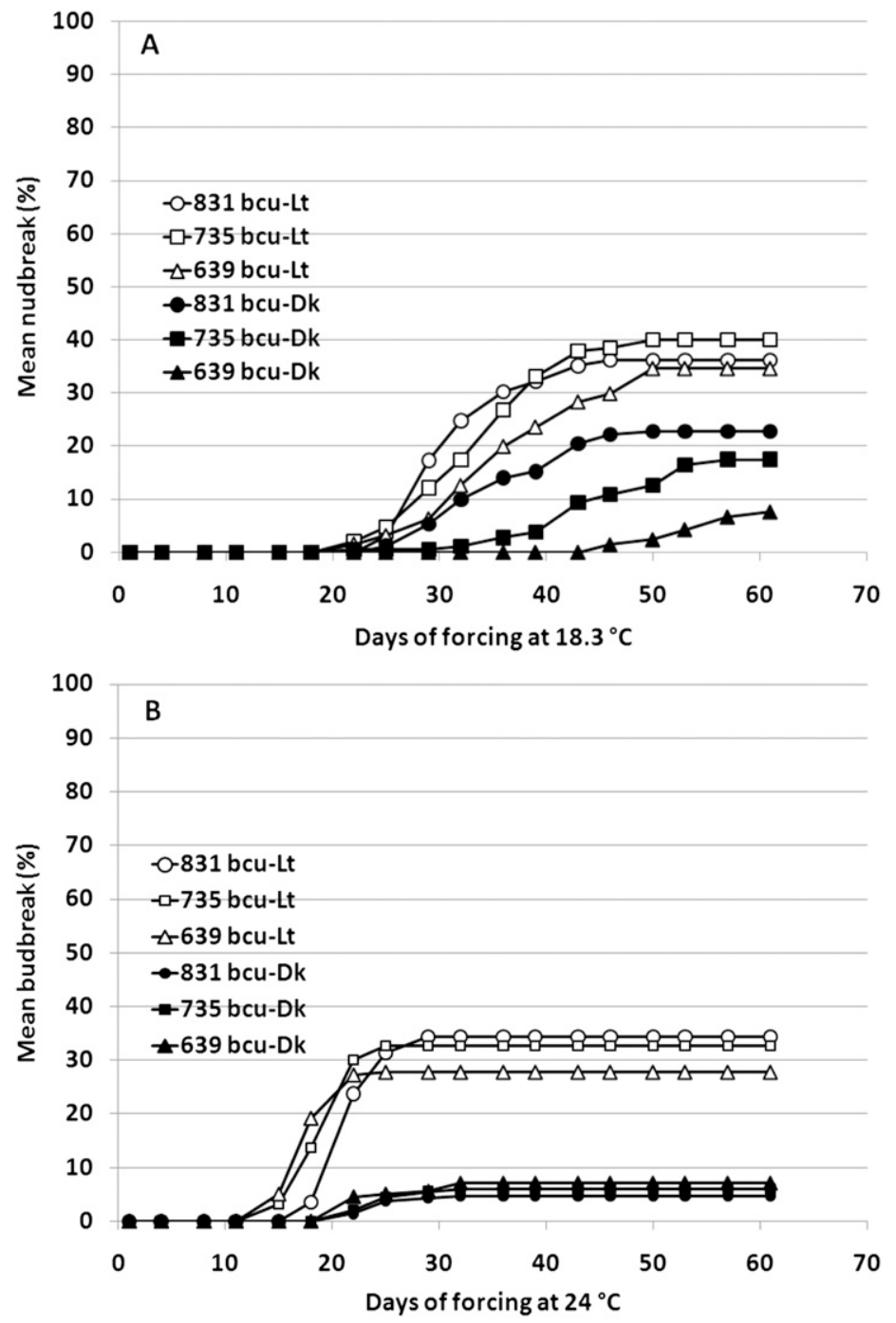

Fig. 4. Effect of light regime, amount of chilling, and temperature during forcing on 'Sunland' peach flower budbreak in 2008-2009. Forced at 18.3 (A) or $24^{\circ} \mathrm{C}(\mathbf{B})$ in darkness (Dk $=$ solid symbols) or a diurnal cycle with $12 \mathrm{~h}$ light $(\mathrm{Lt}=$ open symbols $)$. Twigs cut from orchard after $543 \mathrm{bcu}$ and provided 4,8 , or $12 \mathrm{~d}$ additional chilling at $4{ }^{\circ} \mathrm{C}$ giving totals of 639,735 , and $831 \mathrm{bcu}$, respectively. differences between the light and dark treatments were still clear, budbreak in the light treatments was less than expected, perhaps because of the lower light levels in the boxes resulting from the translucent cover. At the higher forcing temperature (Fig. 4B), budbreak was rapid at all levels of chilling when forced in light, but the final percentages were lower than for those forced at a lower temperature (Fig. 4A). At the lower forcing temperature, promotive effects of increased levels of chill were more obvious. Recent work suggests phytochrome and the related phytochrome-interacting factors play a role in dormancy, among many other processes, and that role is influenced by temperature (Tanino et al., 2010). For example, reversion of the active form phytochrome $\mathrm{P}_{\mathrm{fr}}$ to the inactive form $\mathrm{P}_{\mathrm{r}}$ occurs faster in warmer temperatures.

Harrington et al. (2010) suggested the term "critical cu" to describe the minimum number of cu required for budbreak. Their "optimal cu" level occurs when further chilling does not reduce the heat requirement to budbreak. Between these points, additional chilling reduces the amount of heat needed for budbreak in peach (Okie and Blackburn, 2011). During this same period, light exposure also reduces heat to budbreak relative to forcing in darkness. Because the natural outdoor environment includes diurnal light, our results suggest that darkness during forcing is inhibitory rather than that light is promotive, although the two possibilities are difficult to distinguish. It should be pointed out that these experimental light levels ( $P P F D$ up to 60 $\left.\mu \mathrm{mol} \cdot \mathrm{m}^{-2} \cdot \mathrm{s}^{-1}\right)$ are only a fraction of typical sunlight, which reaches $\approx 1000 \mu \mathrm{mol} \cdot \mathrm{m}^{-2} \cdot \mathrm{s}^{-1}$ in early winter at Byron, GA. Relative to forcing in darkness, light appears to allow budbreak comparable to that expected for buds with $\approx 50$ to $100 \mathrm{bcu}$ of additional chilling based on comparing the budbreak curves. If light has the same promotive effect on buds in the orchard, perhaps one could delay bloom by covering the buds at the time of critical cu with an opaque, non-phytotoxic material.

Leaf buds (Table 1) required more chilling than flower buds and usually lateral buds required more chilling than terminal buds ('Flordaprince' and 'Flordadawn' data not shown), as others have reported (Gariglio et al., 2006). Light generally enhanced the rate and total percentage of budbreak for the intermediate cut dates of each cultivar (Table 1). For example, 'Sunland' in 2007-2008 with 614 bcu had greater than $40 \%$ floral budbreak in the light (Fig. 3) but no leaf budbreak (Table 1). For twigs cut a week later $(717 \mathrm{bcu})$, floral budbreak reached $50 \%$ in the dark and $80 \%$ in the light (Fig. 3), whereas leaf budbreak was $25 \%$ or less (Table 1 ). As expected, increased natural chilling received in the field for a given cultivar increased the percentage of leaf budbreak while reducing the mean time for budbreak.

Color of light. The initial 2006-2007 test using LED light sources showed that exposure to yellow and red light during forcing 
promoted flower budbreak in comparison with blue and dark (Fig. 5). Mean time for 'Juneprince' to reach $50 \%$ budbreak after 798 bcu in the field was $9.4 \mathrm{~d}$ for yellow light, 11.3 for red, and 17.7 for those in the dark (Fig. 5). Those in blue light reached $45 \%$ in $15 \mathrm{~d}$ but did not reach $50 \%$. 'Sunland' after 897 bcu reacted similarly, reaching 50\% budbreak in $14.5 \mathrm{~d}$ for yellow light and $15.5 \mathrm{~d}$ for red light, whereas blue and dark broke more slowly and only reached $\approx 30 \%$ (Fig. 5 ). After 84 bcu more (plus substantial natural heat) in the field, 'Sunland' flower buds emerged rapidly for all treatments (Fig. 5). For both cultivars, leaf budbreak was also enhanced by exposure to red and yellow light with a higher percentage of buds breaking in shorter time relative to blue and dark, particularly for the lateral buds (Table 2).

In 2008, floral budbreak of 'Sunland' was also affected by wavelength. Displaying the budbreak data in relation to the peak wavelength in the light shows the importance of the 600 - to 650 -nm range in promoting budbreak (Fig. 6). Budbreak increased with chilling exposure. After $800 \mathrm{bcu}$, fluorescent, yellow, and red treatments broke bud the fastest, whereas the dark treatment was the slowest (Fig. 6, solid bars). After 900 bcu, three groups were apparent: fluorescent, red, and yellow broke fastest followed by green and incandescent with blue, infrared, and dark the slowest (Fig. 6, gray bars). After $1000 \mathrm{bcu}$, floral budbreak was only slightly increased for the fastest group, whereas the slower treatments began to catch up with all visible light treatments exceeding $50 \%$ break but dark and infrared treatments lagging behind (Fig. 6, white bars). In this experiment, buds received all their later chilling artificially so that all three sets had similar amounts of effective heat (essentially none) at the time they were put at forcing temperature. Thus, changes in percent budbreak and rate of budbreak are solely a function of light treatment and amount of chilling. Floral budbreak rates for the red and yellow treatments after $800 \mathrm{bcu}$ were similar to that of dark control after $1000 \mathrm{bcu}$, reaching 40\% after $\approx 30 \mathrm{~d}$, suggesting the light exposure produced an effect corresponding to an additional $200 \mathrm{bcu}(8 \mathrm{~d})$ of chilling. Leaf budbreak was relatively low after $800 \mathrm{bcu}$, regardless of light treatment (Table 3). After $900 \mathrm{bcu}$, exposure to red or yellow light enhanced both terminal and especially lateral break, especially relative to infrared and dark. No twigs of blue, infrared, or dark treatments had three or more lateral buds break, although a few had a single bud to break. For the 1000 bcu treatment, both terminal and lateral break occurred on all treatments with only infrared laterals lagging behind. The increase in lateral budbreak for the dark treatment was quite dramatic as chilling increased from 900 to $1000 \mathrm{bcu}$, going from $0 \%$ to $58 \%$.

During the time from critical to optimal $\mathrm{cu}$, budbreak is promoted by red, yellow, and fluorescent light when compared with blue, green, infrared, or no light. Fluorescent light
Table 1. Effect of natural chilling (2007-2008) and light exposure during forcing at $18.3^{\circ} \mathrm{C}$ on vegetative budbreak of 'Juneprince' and 'Sunland' peach cultivars $(\mathrm{n}=12)$.

\begin{tabular}{|c|c|c|c|c|c|c|}
\hline \multirow[b]{2}{*}{ Cultivar } & \multirow[b]{2}{*}{ Chilling (bcu) } & \multirow[b]{2}{*}{ Light Exposure (h) } & \multicolumn{2}{|c|}{ Budbreak (\%) } & \multicolumn{2}{|c|}{ Time to budbreak (d) } \\
\hline & & & Terminal & Lateral & Terminal & Lateral \\
\hline \multirow[t]{10}{*}{ Juneprince } & 442 & 0 & 0 & 0 & - & - \\
\hline & & 12 & 0 & 0 & - & - \\
\hline & 469 & 0 & 25 & 0 & 47 & - \\
\hline & & 12 & 56 & 8 & 39 & 47 \\
\hline & 500 & 0 & 17 & 0 & 26 & - \\
\hline & & 12 & 91 & 0 & 33 & - \\
\hline & 614 & 0 & 8 & 0 & 38 & - \\
\hline & & 12 & 42 & 50 & 27 & 30 \\
\hline & 717 & 0 & 67 & 42 & 28 & 32 \\
\hline & & 12 & 67 & 67 & 22 & 22 \\
\hline \multirow[t]{8}{*}{ Sunland } & 614 & 0 & 0 & 0 & - & - \\
\hline & & 12 & 0 & 0 & - & - \\
\hline & 717 & 0 & 17 & 0 & 33 & - \\
\hline & & 12 & 9 & 25 & 27 & 26. \\
\hline & 818 & 0 & 43 & 92 & 27 & 27 \\
\hline & & 12 & 90 & 92 & 24 & 24 \\
\hline & 862 & 0 & 57 & 75 & 19 & 19 \\
\hline & & 12 & 89 & 92 & 18 & 18 \\
\hline
\end{tabular}
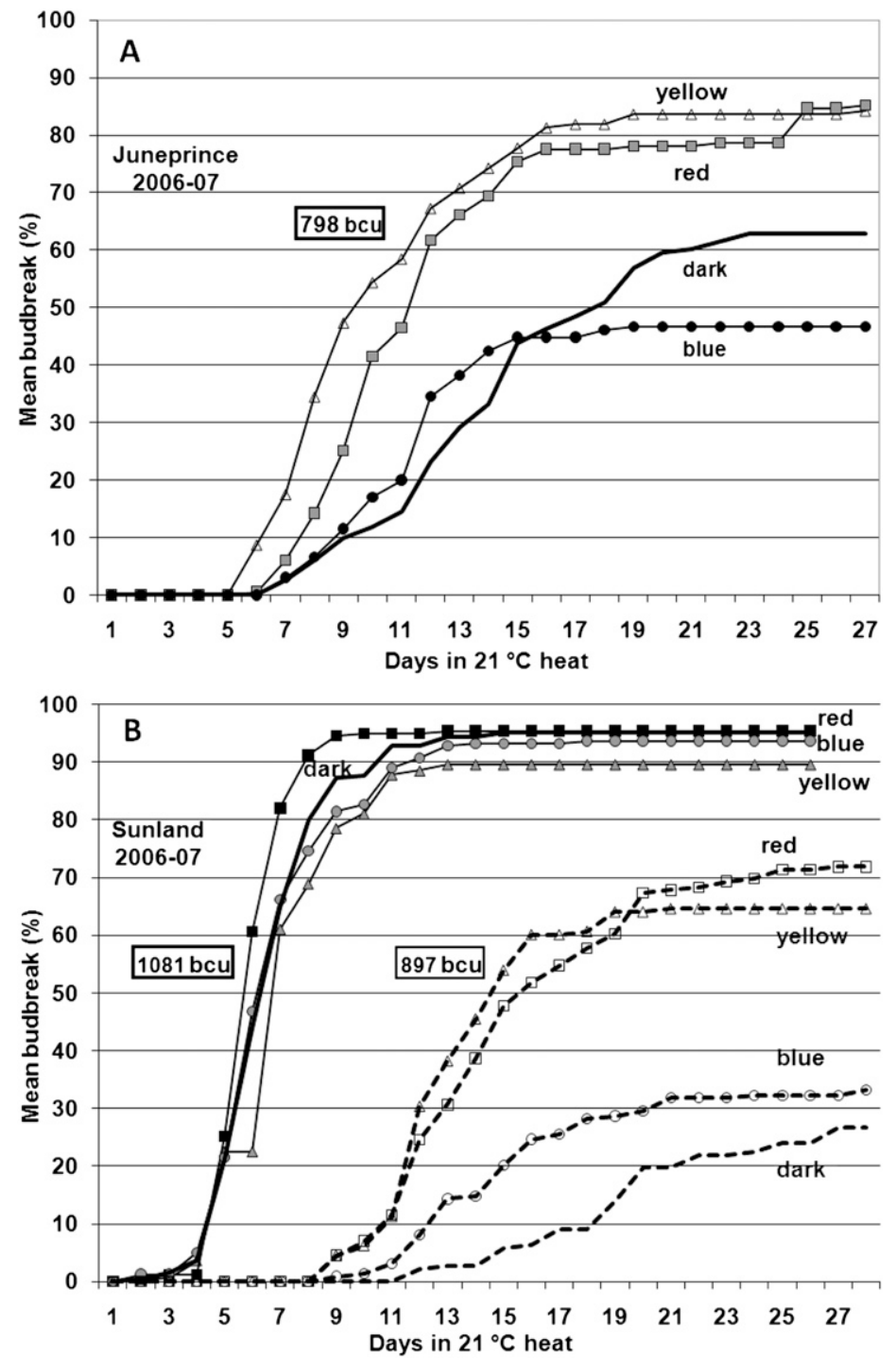

Fig. 5. Effect of color of light on budbreak of peaches 'Juneprince' (A, after 798 bcu) and 'Sunland' (B, after 897 and $1081 \mathrm{bcu}$ ) in 2006-2007 (bcu = Byron chill units). Twigs received natural chilling and were forced at $21^{\circ} \mathrm{C}$. 
has a prominent peak at $612 \mathrm{~nm}$ (between the spectrums of the yellow and red bulbs; Fig. 1) and no major far-red component (700 to $800 \mathrm{~nm}$ ), suggesting the phytochrome system may be involved as Erez et al. (1966) proposed for leaf budbreak. The most promotive light treatments (yellow, red, fluorescent) have higher red:far-red ratios (open circles, Fig. 6) and would maintain more phytochrome as the active $P_{F R}$ form (Smith, 2000). Treatments with a low red:far-red ratio resulting from either lacking red wavelengths (dark, blue, infrared) or with a high far-red component (incandescent) would have higher levels of the inactive $\mathrm{P}_{\mathrm{R}}$ form. The green light treatment has an inflated ratio despite minimal red wavelengths as a result of extremely low irradiance levels in the far-red range. On the other hand, the ratio for fluorescent light is reduced as a result of a small peak in the farred range. Thus, the red:far-red ratio alone is not a good predictor of which wavelengths are promotive to budbreak, but the irradiance of red wavelengths (Fig. 1) must also be considered.

At the time when light promotes budbreak, the flower buds are beginning to swell, which likely would alter the filtering effects of the bud scales and allow increased transmission of wavelengths below $700 \mathrm{~nm}$. Light reaching the bud primordia might have an increased red:far-red ratio, but whether this change is involved in the promotive effects of light is unknown. Possibly a certain ratio triggers further budbreak, and hence low red light treatments such as we used would delay this triggering effect until further bud swelling occurred. In contrast, treatments with higher levels of red wavelengths might reach this trigger ratio earlier in the swelling process.

Light effects on floral budbreak in our tests are different from those previously reported (Erez et al., 1966; Lavee and Erez, 1969). In their tests, green or no light during forcing promoted more floral budbreak $(20 \%$ to $28 \%$ ) than red, blue, or white (fluorescent)

Table 2. Effect of light regime on vegetative budbreak of 'Juneprince' (after $798 \mathrm{bcu}$ ) and 'Sunland' (after 897 bcu) peach twigs $(n=12)$ in $2006-2007 .{ }^{.}$

\begin{tabular}{lcccccc}
\hline & & \multicolumn{2}{c}{ Budbreak (\%) } & & \multicolumn{2}{c}{ Time to budbreak (d) } \\
\cline { 3 - 4 } Cultivar & Light regime & Terminal & Lateral & & Terminal & Lateral \\
\hline Juneprince & Yellow & 100 & 100 & 14 & 15 \\
& Red & 100 & 100 & 14 & 15 \\
& Blue & 75 & 17 & 17 & 23 \\
& Dark & 75 & 17 & 29 & 43 \\
\multirow{3}{*}{ Sunland } & Yellow & 100 & 83 & & 18 & 22 \\
& Red & 100 & 100 & 18 & 19 \\
& Blue & 33 & 0 & 24 & 35 \\
\hline
\end{tabular}

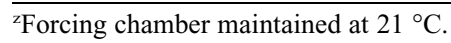

$\mathrm{bcu}=$ Byron chill units light $(\approx 15 \%)$. Their light levels were likely lower than those in our test, because they used colored filters placed over $20-\mathrm{W}$ fluorescent tubes. However, the filters were not very wavelength-specific, and all allowed substantial far-red light to also pass through. Also, we held twigs in Floralife rather than water and removed buds as they broke, which they did not. The biggest difference was probably the chilling status of the twigs. Their cuttings were well chilled: for $21 \mathrm{~d}$ after winter chilling or $89 \mathrm{~d}$ in the dark before forcing. Cuttings in our tests received only natural chilling in 2006-2007 and 2007-2008 and received only 4 to $12 \mathrm{~d}$ supplemental chilling in 2008-2009. With the exceptions of the final harvest dates, most of our treatments resulted in buds that were "underchilled," which is when we saw the largest difference between light and dark treatments. Our results for vegetative buds agree with previous reports in showing leaf budbreak was higher when twigs were forced in light compared to dark, with red and white more effective than blue or green (Erez et al., 1966; Lavee and Erez, 1969).

\section{Conclusions}

Within limits, increasing levels of chilling result in increased flower and leaf budbreak rates and levels. Higher budbreak rates translate to fewer heat units to reach the same level of budbreak. Peach flower and leaf buds at the critical cu stage and forced in fluorescent, red, or yellow light break faster and more completely than those forced in green, blue, infrared, or no light. The promotive effect of light during forcing is less apparent when the twig has received enough natural chill and

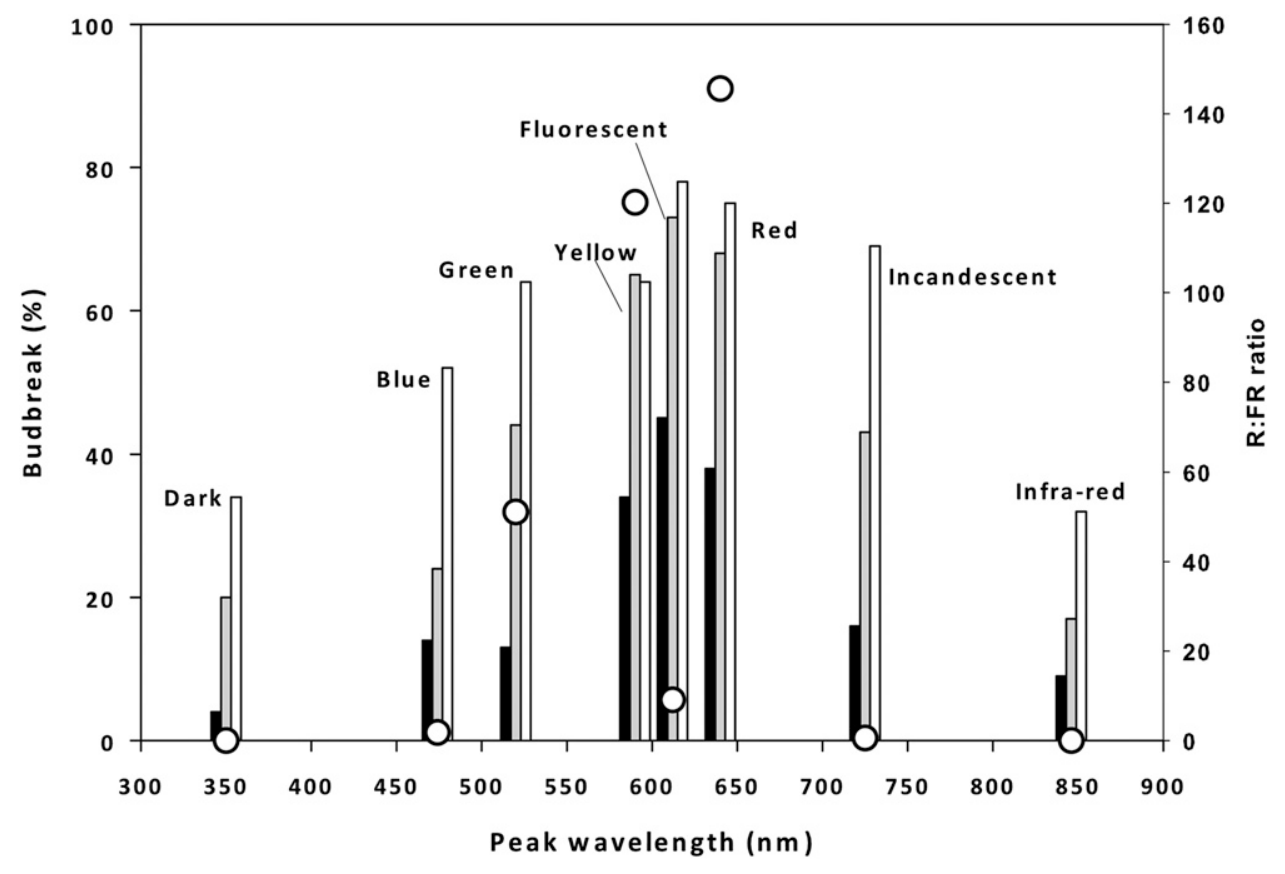

Fig. 6. Effect of light during forcing on floral budbreak of 'Sunland' peach. Budbreak after $28 \mathrm{~d}$ forcing at $18.3^{\circ} \mathrm{C}$ for twigs exposed to chilling levels of 800 (black bar), 900 (gray bar), or $1000 \mathrm{bcu}$ (white bar). Light sources arranged by primary wavelength (except dark control shown at $350 \mathrm{~nm}$ ). Fluorescent source had a second main peak at $546 \mathrm{~nm}$, whereas incandescent source had output increasing from 450 to $850 \mathrm{~nm}$. Circle shows a broad-range red:far-red light ratio for each light source (using total irradiance for 600 to $700 \mathrm{~nm}$ for red and 700 to $800 \mathrm{~nm}$ for far-red). bcu = Byron chill units. 
Table 3. Effect of chilling and light source on vegetative budbreak (2007-2008) of 'Sunland' peach twigs held at $18.3{ }^{\circ} \mathrm{C}$.

\begin{tabular}{|c|c|c|c|c|c|}
\hline \multirow[b]{2}{*}{ Chilling $(\mathrm{bcu})^{\mathrm{z}}$} & \multirow[b]{2}{*}{ Light source ${ }^{y}$} & \multicolumn{2}{|c|}{ Budbreak (\%) } & \multicolumn{2}{|c|}{ Time to budbreak (d) } \\
\hline & & Terminal & Lateral & Terminal & Lateral \\
\hline \multirow[t]{8}{*}{800} & Dark & 0 & 0 & - & - \\
\hline & Blue & 8 & 0 & 32 & - \\
\hline & Green & 0 & 0 & - & - \\
\hline & Yellow & 27 & 33 & 37 & 41 \\
\hline & Red & 17 & 25 & 26 & 40 \\
\hline & Fluor. & 27 & 8 & 36 & 27 \\
\hline & IR & 0 & 0 & - & - \\
\hline & Incan. & 0 & 0 & - & - \\
\hline \multirow[t]{8}{*}{900} & Dark & 33 & 0 & 35 & - \\
\hline & Blue & 50 & 0 & 32 & - \\
\hline & Green & 50 & 25 & 31 & 42 \\
\hline & Yellow & 100 & 75 & 31 & 36 \\
\hline & Red & 92 & 58 & 31 & 33 \\
\hline & Fluor. & 55 & 50 & 25 & 31 \\
\hline & IR & 0 & 0 & - & - \\
\hline & Incan. & 25 & 8 & 34 & 39 \\
\hline \multirow[t]{8}{*}{1000} & Dark & 60 & 58 & 31 & 35 \\
\hline & Blue & 82 & 42 & 23 & 31 \\
\hline & Green & 71 & 67 & 24 & 28 \\
\hline & Yellow & 87 & 83 & 24 & 29 \\
\hline & Red & 100 & 92 & 23 & 27 \\
\hline & Fluor. & 100 & 100 & 23 & 26 \\
\hline & IR & 73 & 17 & 34 & 45 \\
\hline & Incan. & 56 & 42 & 23 & 27 \\
\hline
\end{tabular}

${ }^{\mathrm{z}}$ Chilling up to 437 bcu received naturally, above that received in a $4{ }^{\circ} \mathrm{C}$ dark chamber.

${ }^{\mathrm{y}}$ Fluor. $=$ fluorescent; Incan. $=$ incandescent; IR = infrared; other colors light-emitting diode bulbs.

heat (in the presence of daylight) for at least some flower buds to be within a week or so (at $18^{\circ} \mathrm{C}$ ) of emergence. The promotive effect apparently occurs during the transition from endodormancy, when chilling accumulation is occurring, to ecodormancy, when adequate heat accumulation can produce budbreak. Perhaps phytochrome speeds this transition in some way, because the response is promoted more by light sources with a substantial red component and a limited far-red component than by other sources.

The light regime should be considered and fully characterized when conducting experiments on peach buds using artificial conditions. Depending on the stage of the buds used, light regime can influence budbreak of both floral and vegetative buds. Comparisons between experiments in which twigs are forced in the dark with those forced in light may be confounded by light effects.

\section{Literature Cited}

Allan, P., G. Rufus, G.C. Linsley-Noakes, and G.W. Matthee. 1995. Winter chill models in a mild subtropical area and effects of constant $6^{\circ} \mathrm{C}$ chilling on peach budbreak. Acta Hort. 409: 9-17.

Anderson, J.L., E.A. Richardson, and C.D. Kesner. 1986. Validation of chill unit and flower bud phenology models for 'Montmorency' sour cherry. Acta Hort. 184:71-78.

Chandler, W.H., M.H. Kimball, G.L. Philp, W.P. Tufts, and G.P. Weldon. 1937. Chilling requirements for opening of buds on deciduous orchard trees and some other plants in California. Univ. Calif. Agr. Exp. Bull. 611.
Erez, A., G.A. Couvillon, and C.H. Hendershott. 1979. The effects of cycle length on chilling negation by high temperatures in dormant peach buds. J. Amer. Soc. Hort. Sci. 104:573-576.

Erez, A., S. Fishman, G.C. Linsley-Noakes, and P. Allan. 1990. The dynamic model for rest completion in peach buds. Acta Hort. 276:165174.

Erez, A., S. Lavee, and R.M. Samish. 1968. The effect of limitation in light during the rest period on leaf bud break of the peach (Prunus persica). Physiol. Plant. 21:759-764.

Erez, A., R.M. Samish, and S. Lavee. 1966. The role of light in leaf and flower bud break of the peach (Prunus persica). Physiol. Plant. 19:650659.

Falusi, M. and R. Calamassi. 1990. Bud dormancy in beech (Fagus sylvatica L.). Effect of chilling and photoperiod on dormancy release of beech seedlings. Tree Physiol. 6:429-438.

Fishman, S., A. Erez, and G.A. Couvillon. 1987. The temperature dependence of dormancy breaking in plants: Simulation of processes studied under controlled temperatures. J. Theor. Biol. 126:309-322.

Freeman, M.W. and G.C. Martin. 1981. Peach floral bud break and abscisic acid content as affected by mist, light, and temperature treatments during rest. J. Amer. Soc. Hort. Sci. 106:333-336.

Gariglio, N., D.E. González Rossia, M. Mendow, C. Reig, and M. Agusti. 2006. Effect of artificial chilling on the depth of endodormancy and vegetative and flower budbreak of peach and nectarine cultivars using excised shoots. Sci. Hort. 108:371-377.

Hanninen, H. and K. Kramer. 2007. A framework for modeling the annual cycle of trees in boreal and temperate regions. Silva Fennica 41:167205.
Harrington, C.A., P.J. Gould, and J.B. St. Clair. 2010. Modeling the effects of winter environment on dormancy release of Douglas-fir. For. Ecol. Mgt. 259:798-808.

Heide, O.M. 2008. Interaction of photoperiod and temperature in the control of growth and dormancy of Prunus species. Sci. Hort. 115: 309-314.

Heide, O.M. and A.K. Prestrud. 2005. Low temperature, but not photoperiod, controls growth cessation and dormancy induction and release in apple and pear. Tree Physiol. 25:109-114.

Lavee, S. and A. Erez. 1969. The effect of light types on leaf and flower bud burst of excised peach shoots. HortScience 4:290-291.

Linkosalo, T., R. Hakkinen, and H. Hanninen. 2006. Models of the spring phenology of boreal and temperate trees: Is there something missing? Tree Physiol. 26:1165-1172.

Linsley-Noakes, G.C., M. Louw, and P. Allan. 1995. Estimating daily positive Utah chill units from maximum and minimum temperatures. J. S. Afr. Soc. Hort. Sci. 5:19-24.

Mahmood, K., J.G. Carew, P. Hadley, and N.H. Battey. 2000. Chill unit models for the sweet cherry cvs Stella, Sunburst and Summit. J. Hort. Sci. Biotechnol. 75:602-606.

Okie, W.R. 1998. Handbook of peach and nectarine varieties. USDA-ARS Agr. Handbook No. 714.

Okie, W.R. and B. Blackburn. 2011. Increasing chilling reduces heat requirement for floral budbreak in peach. HortScience 46:245-252.

Pukacki, P. and M. Giertych. 1982. Seasonal changes in light transmission by bud scales of spruce and pine. Planta 154:381-383.

Pukacki, P., M. Giertych, and W. Chatupka. 1980. Light filtering functions of bud scales in woody plants. Planta 150:132-133.

Richardson, E.A., J.L. Campbell, and R.H. Campbell. 1986. The Omnidata biophenometer (TA45-P): A chill unit and growing degree hour accumulator. Acta Hort. 184:95-99.

Richardson, E.A., S.D. Seeley, and D.R. Walker. 1974. A method for estimating the completion of rest for 'Redhaven' and 'Elberta' peach trees. HortScience 9:331-332.

Seeley, S.D. 1996. Modeling climatic regulation of bud dormancy, p. 361-376. In: Lang, G.A. (ed.). Plant dormancy: Physiology, biochemistry and molecular biology. CAB Intl., Wallingford, UK.

Smith, H. 2000. Phytochromes and light signal perception by plants-An emerging synthesis. Nature 407:585-591.

Solymosi, K. and B. Boddi. 2006. Optical properties of bud scales and protochlorophyll(ide) forms in leaf primordia of closed and opened buds. Tree Physiol. 26:1075-1085.

Tanino, K.K., L. Kalcsits, S. Silim, E. Kendall, and G.R. Gray. 2010. Temperature-driven plasticity in growth cessation and dormancy development in deciduous woody plants: A working hypothesis suggesting how molecular and cellular function is affected by temperature during dormancy induction. Plant Mol. Biol. 73:4965.

Waring, P.F. 1953. Growth studies in woody species V. Photoperiodisin in dormant buds of Fagus sylvatica L. Physiol. Plant. 6:692-706.

Weinberger, J.H. 1950a. Chilling requirements of peach varieties. Proc. Amer. Soc. Hort. Sci. 56: 122-128.

Weinberger, J.H. 1950b. Prolonged dormancy of peaches. Proc. Amer. Soc. Hort. Sci. 56:129133. 